\title{
Primitive Socialist Accumulation, Readjustment and Reform (1953-1978)
}

\section{Introduction}

In this chapter we focus on the Maoist economic paradigm, which, with minor interruptions, guided Chinese economic development until the reforms introduced by Deng Xiaoping in 1978. The strategy for economic development under the First Five Year Plan (1953-1957) relied heavily on Soviet theory and experience, and in the first decade of the Maoist era, the Soviet discourse would continue to serve as a referent for Chinese economists and leadership. In line with the work of Soviet economists Fel'dman and Preobrazhensky, Chinese leadership adopted a strategy of accelerated accumulation, wherein the appropriation of agricultural output provided the necessary investment for the planned expansion of industry.

Following the period of the First Five Year Plan, emerging economic imbalances prompted a reevaluation of the notions of centralized planning and the intersectoral transfer of resources. Various state leaders and economists called for the partial reinstatement of market allocation and a more balanced trajectory of growth. However, these suggestions failed to make a lasting impact. At times, Mao proved sympathetic to the notion of developing agriculture and industry on a more even keel. However, the Chairman seemed to have ultimately attributed problems of development to a lack of ideological rectitude among Party cadres and the working masses, rather than any intrinsic defect of the strategy of accelerated accumulation. Notwithstanding its marginal influence on Maoist-era economic policy, the economic discourse of the 1950s and 1960s had a profound impact on the Chinese state leaders who ascended to power in 1978. Deng Xiaoping's policies of economic reform and adjustment, which brought about a definitive break with the Soviet strategy of socialist development, were defined to a large extent by the discourse on market allocation and sectoral balance of the 1950 s and especially the early 1960 s.

We commence this chapter with a discussion of the foundational socialist theories, which concerned the instruments of allocation, the appropriate relations between industry and agriculture, and the material and ideological foundations of economic development. We then move on to describe the interdependent development of indigenous economic discourse, policy and the 
Maoist-era Chinese economy. We discuss how Maoism stymied attempts to introduce market allocation, but ultimately failed to suppress support for reform and readjustment, which would subsequently provide the basic conceptual parameters for the development of China's economic paradigm of market socialism.

\section{Theoretical Foundations and Issues of Communist Development}

China's Maoist economic paradigm was informed by three central concerns within socialist economy theory. The first of these related to the means by which resources would be allocated throughout the economic system. The second pertained to the means by which a developed, socialist economy could be established in the most expedient manner. At least during the Maoist era, the Chinese paradigm coincided with the Soviet interpretation on these first two issues. Where it differed most markedly, however, was with respect to the third issue, that is, the roles attributed to the material and ideological conditions within economic development. Below, we discuss these three theoretical issues in greater detail. Besides providing the discursive context for the development of the indigenous economic debate, this section gives a brief introduction of concepts that may be foreign to readers unfamiliar with Marxian theory and the economic discussions that prevailed within the Soviet Union in the 1920 .

\section{The Law of Value and the Law of Planned Proportionate Development}

Expounded in the first chapter of volume one of Marx's Capital and Engels' addendum to the third volume, ${ }^{10}$ the law of value holds that the value of a commodity is determined ultimately by the amount of labor expended in its production.11, 12 While demand and supply influence the exchange value of commodities (that is, the ratio with which one commodity is traded for

10 "Law of Value and Rate of Profit" appeared first as a supplement to the 1894 edition of the third volume of Capital.

11 On the difference between use value, exchange value and value (proper), see Marx (1992, ch. 1).

12 Marx states: "[T] hat which determines the magnitude of the value of any article is the amount of labor socially necessary, or the labor time socially necessary for its production" (Marx 1992, p. 28). By "socially necessary," Marx refers to the average labor time, given prevailing technologies and productivity. 
another), the relative scarcity of commodities (or the capital utilized in their production) cannot explain that increment of differential value which remains when supply and demand are in equilibrium. Rather, this value must derive from an inherent feature shared by all commodities which is independent of the process of exchange. This commonalty, argued Marx, is the human effort (i.e. labor) expended in the act of production. ${ }^{13}$ It follows that, under equilibrium conditions, prices within the market are primarily determined by the respective stocks of labor internalized within commodities. Although the above statement appears to be a general economic maxim in the vein of the labor theories of Adam Smith and David Ricardo, Marx considered his law of value to relate specifically to capitalism. The abstract notion of value-as something different from the immediate utility of a good, that is, its use value - within the capitalist mode of production could only develop due to the equally abstract form of commoditized wage labor. ${ }^{14}$ It was because the amount (or rather hours) of commoditized wage labor expended in the production of one commodity could be directly compared to that in another that the value of each could be determined..$^{15}$ Through market competition, the law of value would spontaneously assert itself; competition would exert downward pressure on

13 Moreover, the constitutive function of labor within value was held to remain even in the face of fluctuation resultant from commodity circulation, although expressing itself as a tendency rather than a fixed proportion. See Engels, "Law of Value and Profit," in Marx and Engels (1990).

14 When discussing the law of value, Marx refers not to "concrete labor," i.e. the specific task preformed in order to produce a particular item (e.g. the sewing required to produce a shirt), but rather to "abstract labor," i.e. the general, undifferentiated act of producing value. Under capitalism, such abstract labor is exchanged within markets much like other factors of production, hence "commoditized" (see Marx 1992, ch. 1).

15 Although the law of value provided the main allocative principle within capitalist economies, Marx held that the prices of production — that is, the price point at which a particular commodity generally tends to be sold - to be only broadly constrained by, but not determined by, the law of value. Rather, the price of production is constituted by the costs of production - including those expended on labor, and the objects (i.e. material) and instruments of labor-and an average rate of profit. The average rate of profit in turn is determined by the realized surplus value, that is, value created by labor that is not restituted to the worker by way of wages. Since surplus value is created through the expropriation of labor value, the rate of profit depends on the ratio between constant capital and labor within production; what Marx calls the organic composition of capital. It follows that in industries where the organic composition of capital is lower (i.e. laborintensive production) the rate of profit would be higher (Marx and Engels 1990, ch. 45). The differences in the organic composition of capital between industries would result in persistently diverging rates of profit, were it not for the fact that competition would 
prices, but producers would be unwilling to supply goods at prices below the cost of production. ${ }^{16}$ This spontaneous and anarchistic process of regulation by the law of value would, ${ }^{17}$ however, prompt aberrations in supply and demand, causing the capitalist mode of production to undergo constant fluctuations and periodic crisis.

The socialization and unification of production would abolish the law of value, eliminating the irregularities of capitalist production and the wasteful duplication of effort and resources impelled by competition. Rather, production under socialism is governed by the law of planned, proportionate development. The overall objective of planned development was to be ultimately provided by the economic law of socialism, defined by Stalin as follows: "[M]aximum satisfaction of the constantly rising material and cultural requirements of the whole of society is the aim of socialist production; continuous expansion and perfection of socialist production on the basis of higher techniques is the means for the achievement of the aim" ([1952] 1972, p. 80). This required proportionate economic development, and first and foremost an appropriate relationship between the means of production and the production of consumer goods.

Realization of the continuous increase of production would require the rapid and comprehensive expansion of heavy industry, which provides production technology (Institute of Economics of the Academy of Sciences of the USSR 1957, ch. 30). Eventually, planned and proportionate economic devel opment would become the purview of the people. However, in the interim period, in which the material basis remained relatively underdeveloped and the socialization of production incomplete, the task of planning would fall on the state. Opinion differed on how the state ought to proceed with the task of economic planning. In particular, controversy existed regarding the interpretation of "proportionate" development and the role of the law of value under socialism. The former issue will be discussed in detail in the next section. Here, we focus on the Soviet debate on the law of value. ${ }^{18}$

prompt investment to flow toward industries with the highest rates of profit, resulting in excess production and causing industrial profits to converge to the average rate of profit.

16 The spontaneous operation of the law of value (akin to Smith's concept of the invisible hand) was referred to in socialist theory as "the economic law of competition and anarchy of production" (see Institute of Economics of the Academy of Sciences of the USSR 1957, ch. 4).

17 "Spontaneous" and "anarchistic" because the operation of the law of value was not coordinated by any particular actor or central authority.

18 Note that Marx's discussion of communism was limited to the "Communist Manifesto," which enumerated a host of conditions characteristic of communist society (see chapter 2 
It was generally understood that once the transition toward communism was completed, the law of value would dissipate..$^{19} \mathrm{After}$ all, the law of value was in itself an artifact of capitalism, a result of the social relations of production that organized production into abstract labor and commodities. Under communism, workers would not toil for wages, but would work simply to fulfil social need, weighing material gains against the time devoted to labor (Bukharin and Preobrazhensky 1966). In consequence, the intermediary concepts of exchange value and production prices could be dispensed with, and the organization of production would be based directly on labor time and use value. However, in the transition from capitalism to communism, when the material conditions of production would have to be developed, accumulation, and thus the creation of surplus value, would remain a necessity. Moreover, until the socialization of ownership was completed, planned and commodity production would exist side by side. Some-notably the Russian economist Evgenii Preobrazhensky - argued that the laws of value and planned, proportionate development were inherently incompatible and antagonistic. Accordingly, the objective of socialist development was to expand socialist production by the progressive incorporation of capitalist commodity production into the state-controlled industrial complex, promoting the twin objectives of the development of the factors of production and the relations of production (Freeman, Kliman and Wells 2004, ch. 13). ${ }^{20}$ Preobrazhensky formalized his perspective in the theory of accelerated accumulation (see the following section), which would provide the foundation for the Chinese strategy of industrialization.

However, Stalin, whose writings also exerted considerable influence on the initial Chinese economic strategy, ${ }^{21}$ held a different opinion. During socialist development, labor would be compensated with consumer goods. He argued that, while the nature of these commodities would be specified by plan, the law of value would still influence their production by determining their relative exchange ratios. Moreover, Stalin saw use for prices reflecting the law of

of the manifesto), but did not expound the actual organization of the system of production, or the concrete means by which to transit from capitalist to socialist, and eventually, communist society.

19 Value, like the law of value, is a historical category connected with the existence of commodity production. With the disappearance of commodity production, value and its forms and the law of value also disappear (Stalin [1952] 1972, p. 22).

20 The factors of production are comprised of labor and capital; the relations of production refer to the social organization of production. We discuss these concepts in more detail in the following sections.

21 That is, during the period of the First Five Year Plan. However, the Stalinist model would subsequently be heavily criticized by Mao, see Mao (1969). 
value within national accounting, believing it would incentivize producers to focus on productivity and efficiency (Stalin [1952] 1972, ch.3). He did, however, categorically dismiss the idea of allowing the law of value to exert its regulatory function. Said Stalin: "[If] the law of value regulates the 'proportions' of labor distributed among the various branches of production... it would be incomprehensible why our light industries, which are the most profitable, are not being developed to the utmost, and why preference is given to our heavy industries, which are often less profitable, and sometimes altogether unprofitable" (Stalin [1952] 1972, pp. 22, 23).

A similar divergence in perspectives on the utility and ideological stature of the law of value would come to characterize the Chinese debate, resulting in heated debate between China's leaders. The implications of this discussion were extensive. Discussions on efficiency criteria and price calculations would be unthinkable without a discussion of commodity production and exchange and the law of value. Moreover, because Preobrazhensky had directly associated the laws of value and planned, proportionate development with the operation of commodity (e.g. consumer goods) and socialist production respectively, the discussion on prices became inextricably related to the central issue of sectoral development.

\section{Accelerated Accumulation and Balanced Growth}

In Marx's analysis, growth depends critically on the economic system's capacity to consistently produce surplus value that can be reconverted into productive capital. Simple reproduction occurs when economic activity only creates value sufficient to replenish the stocks of capital and labor expended in that instance of production. Accumulation, by contrast, requires the creation of surplus value (that is, value in excess of the sum invested in capital and labor), which is then used to expand the means of production (Marx 1992, ch. 24). At the aggregate level, accumulation depends on the relationship between the agricultural sector (department 2), which produces goods for direct consumption and the industrial sector (department 1 ), which manufactures the instruments of production. The industrial sector can be further divided into two parts, that which produces equipment for its own enlargement (i.e. basic or heavy industry (department 1a)) and that which manufactures the means of production for agriculture (department $\mathrm{b} b$ ). For accumulation to take place, part of the realized surplus value must be reinvested in industry.

\section{Fel'dman's Theory of Accumulation}

The first economist to focus attention on how the relationship between departments 1 and 2 affected the rate of economic growth was the Soviet economist 
Fel'dman. ${ }^{22}$ According to Fel'dman, when investment is allocated in a manner proportionate to the respective stocks of capital in both departments, the economy will grow in a steady fashion. For the rate of accumulation to accelerate over time, ${ }^{23}$ the proportion of investment in department 1 must be greater than the proportion of investment in department 2. In other words, to initiate rapid economic growth, it is necessary to rapidly expand the capacity of the producer goods sector. ${ }^{24}$ Such accelerated growth will increase the capacity of department $1 \mathrm{a}$ in proportion to departments $1 \mathrm{~b}$ and 2 . The output of sector 2 will continue to grow, although its share of total economic output declines each year. However, because industry manufactures producer goods for agriculture, the efficiency of agricultural production is increased, yielding greater surplus value. This surplus value can subsequently be reinvested in the development of department 1. Fel'dman concluded that by following a strategy of accelerated growth the whole economy would eventually permanently shift to a trajectory of higher growth, although the rate of growth of department 2 output would be temporarily reduced. The time span of this transition would depend on the allocation of capital stock between $1 \mathrm{a}$ and $\mathrm{lb}$ in industry at the initial point of takeoff, and on the proportion of output in department 1 allocated to 1a and $\mathrm{b}$ respectively. Fel'dman's two-sector model of accelerated economic growth, emphasizing heavy industry, became the basis of the economic strategy followed in the USSR until the mid-195os (Nove and Nuti 1976) as well as in China during the First Five Year Plan.

\section{Preobrazhensky and Primitive Socialist Accumulation}

The development of heavy industry, which is the crux of the Fel'dman model, hinged on the transfer of resources from agriculture to industry, such as industrial raw materials and grain supplies for the rapidly expanding urban workforce. In other words, sustaining an accelerated rate of accumulation would require the appropriation of increasing increments of agricultural output until industrialization is completed. Preobrazhensky's concept of "primitive

22 Fel'dman's growth model was originally published in the USSR in 1928. It was introduced to Western readers by Domar (1957). It is discussed in Robinson and Eatwell (1973); Ellman (1979); and translated into English in Spulber (1964).

23 Under the material planning system utilized in socialist economics, the rate of accumulation is calculated as the proportion of fixed capital and working capital. See Bo (1956: pp. 45-62); FBIS 1983 (April 29), "Explanation of Terms Used in the Sixth Five Year Plan," Economic Report, No. 333. In order to ensure compatibility with more recent statistics and international conventions, we will instead provide the rate of gross fixed capital formation, which excludes land purchases and inventories.

Ellman (1979, pp. 112-150); Robinson and Eatwell (1973, pp. 272-293). 
socialist accumulation" was the first to provide explicit support for the transfer of surplus value from agriculture to industry. Preobrazhensky argued that rapid industrialization would have to be sustained through state appropriation of surplus value from "sources outside the complex of the state economy", that is, agriculture (Preobrazhensky 1965, p. 84). The transfer of agricultural surplus value was to be realized through the instrument of "price-scissors," whereby the terms of trade of agriculture vis-à-vis industry would be artificially depressed by a regime of fixed low prices for agricultural products (see Knight 1995). Preobrazhensky said:

Proceeding from what we have said above, we can formulate this law [the fundamental law of primitive socialist accumulation], or at least that part of it which relates to the redistribution of material sources of production, in this way: the more backward economically, petty-bourgeois, peasant a particular country is which has gone over to the socialist organization of production, and the smaller the inheritance received by the socialist accumulation fund of the proletariat of this country when the social revolution takes place, by so much more in proportion will socialist accumulation be obliged to rely on alienating part of the surplus product of pre-socialist forms of economy and the smaller will be the relative weight of accumulation on its own production basis, i.e. the less will be nourished by the surplus product of the workers in socialist industry.

1965 , P. 124

For Preobrazhensky, the model of primitive socialist accumulation provided not only the means of developing the material economic basis, but simultaneously contributed to the aim of socializing the means of production. By advocating the appropriation of surplus value from the commodity sector-and, moreover, by suggesting that the rate of transfer be positively related to the size of the commodity sector-the proportion of the socialist industry within the overall economy would continually increase.

\section{Bukharin and the Limits to Socialist Primitive Accumulation}

Preobrazhensky's views led to spirited polemics with Bukharin, who was in support of a modest rate of accumulation, a more balanced development of industry and agriculture, and non-exploitative agricultural economic policies. ${ }^{25}$ Bukharin formed his views in the wake of the economic problems that resulted from the overambitious targets for accumulation and industrial expansion set

25 See Erlich (196o, pp. 3-97); Nove (1978, pp. 119-135); Spulber (1964, pp. 64-66). 
out in the Soviet Union's First Five Year Plan (1928-1933). Bukharin warned against overstraining capital expenditure (i.e. accumulation) because this would lead to the arrest of construction already initiated, unfavorably affect other branches of the economy, increase the goods famine and ultimately retard overall economic growth: "In their simple-mindedness the ideologists of Trotskyism assume that the maximum annual transfer of means from agriculture into industry would suffice to secure the maximum rate of development for industry. It is however clear that this is not so. The greatest sustained speed is obtained by a combination in which industry develops on the basis afforded by a rapidly growing agriculture" (Bukharin 1928, p. 2294).

In contradistinction to Preobrazhensky and the Trotskyites, Bukharin thus argued for prioritization of agricultural development. Underlying this proposition was an understanding of sectoral interdependencies that was diametrically opposed to that underlying the concept of primitive socialist accumulation. The latter held that the productivity of agriculture could only be realized by the development of industry, and, in particular, that part producing producer goods for agriculture. As such, proponents of accelerated accumulation attributed the strained supply of grain in the late 1920 s to the stunted development of industry (and department $\mathrm{tb}$ in particular). Bukharin was rather of the opinion that the origin of this crisis lay in the discrepancy between the inflated prices for agricultural inputs to industry such as oil and cotton (impelled by the latter's increased capacity for production) and artificially low prices for grain (prompting the transfer of surplus value toward the industry), leading to the neglect of grain production. The solution of this problem, according to Bukharin, was twofold: first, the proportion of appropriated surplus value ought to be reduced to a ratio decisively below its "technical maximum" and, second, greater emphasis ought to be put on agricultural capital construction. Although Stalin, inspired by Fel'dman and Preobrazhensky, would eventually split with Bukharin and launch "the revolution from above" (Lorenz 1978), Bukharin's ideas enjoyed a renaissance in China in the wake of the collapse of the Great Leap Forward.

\section{The Productive Forces and the Relations of Production}

Alongside discussions of the law of value and sectoral relationships, the debate concerning the relations of production and the productive forces constituted a third relative constant in Maoist economic discourse. The productive forces are comprised by the means of labor (the machinery, land etc. required to engage in production) and labor itself. By the relations of production, Marx signified the totality of social relations and interdependencies required to sustain a particular form or epoch of production and exchange (Marx and Engels 
1990, ch. 45). Fundamental characteristics of the relations of production under the capitalism mode of production are the disjunction of labor and the means of labor, due to the latter's agglomeration in the hands of the capitalist class and the concomitant institutionalization of wage labor, and the capitalist appropriation of surplus value.

Marxist-Leninist economic theory holds that attainment of the socialist ideal critically depends on four conditions. The first of these, the completion of the socialization of capital, refers to the transformation of the relations of production. The socialization of capital in turn causes the dissipation of social obstacles to reproduction (e.g. rent-seeking, competition etc.) that exist under capitalism. The full development of the productive forces is realized through perfection of the understanding of material and technical conditions. Jointly, these two factors provide the requisite conditions for the total reproduction of productive forces; that is, the realization of the optimal economic state of the socialist system. Finally, the development of socialist consciousness ensures appropriate distributive relations, and prevents the potential reemergence of social obstacles to production. Whereas the understanding of material conditions and the internalization of the technology of material reproduction develops by an incremental process of learning and instruction, the transformation of social relations must be a revolutionary process. Theoretically, the respective emphasis on material and socialist conditions is dictated by the relative states of each, and most effort would have to be expended on the lesser developed of the two (Schran 1962).

In practice, the interpretative leeway provided by this rather abstract instruction caused a considerable divergence between Chinese and Soviet party leadership. ${ }^{26}$ Within the USSR, Stalin unequivocally emphasized the development of the productive forces, embracing Taylorian concepts of work organization and Fordist standardized manufacturing techniques, deeming them natural complements to, and logical extensions of, central planning (Hughes 2004). No such overtures to the prowess of American industrial organization were made by Mao and his confidants. Mao condemned the forceful nature of the Soviet industrialization and collectivization process which had alienated

26 As this study is concerned with economic development strategies, we will have to abstain from a further discussion of, for example, Mao's "timing theory" and "generative class theory," which he defined by analyzing the different stages of the socialist transition phase and associated forms of class struggle. For an introduction of the concept "timing theory" in connection with a discussion on Mao's views on the political-economic stages of socialist development, see Levy (1975). The concept of "generative class theory" was introduced in Brugger (1978). 
the Russian peasantry by implementing ruthless economic and organizational measures. A similar division over the appropriate roles of technical and social consciousness would emerge between leaders within the Chinese state and Party. In general terms, the primary concern of economic bureaucracy was with the technical aspects of economic development. The CCP, with Mao at the helm, tended to emphasize the development of socialist consciousness amongst the working masses, combining a system of incessant and ubiquitous propaganda and organizational measures (epitomized in the Dazhai and Daqing models) with periodic mass movements such as the Great Leap Forward (Shambaugh 2007). However-as we will expound subsequentlydespite Mao's alleged obsession with revolutionary change, nothing in his general philosophical outlook argues against his belief in the model of primitive socialist accumulation.

By advocating the primacy of the "socialization of consciousness" - in contradistinction to Stalin-Mao set out a course for economic development that diverged markedly from that followed in the Soviet Union. Mao's strategy of "big pushes," seeking to elevate the economy to a higher level through the revolutionary reorganization of the relations of production, was fundamentally at odds with the economic policy of Khrushchev, which embraced partial market operation and lessened the prioritization of industrial development. These differences fueled intense mutual criticism by Chinese and Soviet Party leadership, and precipitated the breakdown of political relations between the two countries in the 196os. While this heralded a period of increasing economic isolation for China, it also provided the conditions for the emergence of a prolific indigenous economic debate, which would prefigure the reforms and adjustments eventually introduced by Deng Xiaoping in the late 1970s. Below, we discuss the reciprocal development of China's economic paradigm, and its economic and political conditions under communism in greater detail.

\section{Economic Discourse and Policy in the Maoist Era (1953-1977)}

\section{The First Five Year Plan (1953-1957)}

In the latter era of the Qing Dynasty, rapid expansion of the population, civil unrest and foreign incursion had resulted in economic stagnation and political impotence. While the establishment of the Republic of China in 1912 spelled the official end of two millennia of imperial rule, warlords continued to administer regions under their purview as local fiefdoms (Schoppa 2000). Constant turmoil and the perpetuation of pre-modern institutions obstructed the process of industrialization which had radically transformed relationships 
of ownership and production in most of the Western world. China's economic backwardness, framed within the ideological backdrop of an inevitable clash between capitalist and socialist societies, led the CCP, seizing power in 1949, to regard rapid industrialization as the major imperative. Accordingly, the first of China's Five Year Plans (wu nian jihua) stated:

The adoption of a strategy of active socialist industrialization and the prioritization of heavy industry is necessary for the establishment of a strong army, satisfaction of the people's needs and the creation of a material foundation for a socialist transformation. Therefore, we must make the establishment of a basis for heavy industry the focus of the Draft of the First Five Year Plan for the Development of the National Economy. ${ }^{27}$

Essentially, the Plan contained five main points:

(1) Highest priority was assigned to the development of heavy industry (producer goods industries);

(2) Main attention was paid to 694 above-norm projects, the core of which were 156 projects to be constructed with Soviet help and assistance;

(3) New industries were to be located close to raw material bases;

(4) Increases in wages were to be kept below increases in the productivity of the working force in order to maintain capital accumulation;

(5) Agriculture was to concentrate on the production of grain and industrial raw materials. Focus was to be put on the need of increasing the agricultural surplus product in order to finance industrialization (Li 1955).

In sum, the First Five Year Plan assigned agriculture to function as the accumulation base for the development of industry, and within the industrial sector the accumulation rate of heavy industry was emphasized. The CCP's template for economic development thus reiterated the basic tenets of the theories of Fel'dman and Preobrazhensky. However, both economic and social conditions and political factors in the 1950 os caused the Chinese socialist paradigm to diverge from the Soviet template. Soviet communism had been established with the support of a discontented industrial proletariat. China, on the other hand, had not yet produced an industrial workforce capable of unleashing a communist revolution. Rather, the peasant class provided the basis for China's socialist development. Due to the backward state of its predominantly agricultural economy, China had yet to reach the stage of economic modernization

27 Zhonghua renmin gongheguo (1955: ch. 1). 
at which it could sustain full-scale accelerated accumulation on the eve of its First Five Year Plan in 1952. By contrast, Russia had already reached this stage at the turn of the 2oth century (Rostow 1960). Table 2 illustrates the comparatively unfavorable Chinese socioeconomic setting.

The implications of these contrasts appear clear. The Soviet strategy, based on the Fel'dman model and Preobrazhensky's "law of primitive accumulation," centered on extracting resources from agriculture to provide capital for heavy industry. This was feasible in the Soviet Union, which boasted a relatively favorable resource base and sizeable grain surplus. In China, the imminent concern was to increase agricultural production to a point at which would be a surplus at all (Yeh 1967). ${ }^{28}$

TABLE 2 Total and per capita output of selected products in China and the Soviet Union at the outset of their First Five Year Plans

\begin{tabular}{lcc}
\hline & $\begin{array}{c}\text { China } \\
(\mathbf{1 9 5 2})\end{array}$ & $\begin{array}{l}\text { Soviet Union } \\
(\mathbf{1 9 2 8})\end{array}$ \\
\hline Population (mln.) & 575 & 147 \\
Urban population (\%) & 12 & 19 \\
GNP per capita (1952 us dollars) & 50 & 240 \\
Cultivated land per rural capita (acres) & 0.7 & 2.3 \\
Grain output per capita & 272 & 566 \\
Per capita industrial output & 111.65 & 241.5 \\
Coal (kg) & 2.37 & 28.91 \\
Steel (kg) & 0.77 & 78.03 \\
Crude oil (kg) & 5.03 & 12.59 \\
Cement (kg) & & \\
\hline
\end{tabular}

SOURCES: CHEN AND GALENSON (1969, PP. 35, 37); ECKSTEIN (1966, P. 20); WORLD BANK (1983, P. 43); YEH (1967, PP. 327-363, 349).

28 The importance of agriculture to Chinese industrialization was acknowledged in the First Five Year Plan. "Agriculture furnishes the conditions for the development of industry. Just like comrade Mao Zedong has said in his 'On coalition government': 'The peasants ... are the main actors within the Chinese industrial market. Only they can provide abundant grain and raw materials, and absorb the major part of industrial products," Zhonghua renmin gongheguo (1955: ch. 1). 
Although China was economically far weaker than the Soviet Union of the late 1920s, agricultural output rose significantly in the former in the early years of the First Five Year Plan. Importantly, the collectivization of agriculture in China had been a much smoother process than in the Soviet Union. Initial support for the communist cause to overthrow the landlord class (Selden 1995) had also rendered China's peasants more receptive to the Party-state's agrarian policies. These policies reiterated the Marxist assumption that socialized industry and collectivized large-scale agriculture are fundamental prerequisites of socialist economic development and growth. ${ }^{29}$ During the first stage of collectivization, output rose significantly, seeming to confirm the wisdom of the adopted agrarian policies. However, the relatively low rate of growth in agriculture during 1956 and 1957 called into question the feasibility of maintaining the rapid rate of industrialization envisaged in the First Five Year Plan. Several amongst China's economic leadership became convinced that the adoption of the Soviet development strategy was altogether incompatible with the realities of the Chinese setting.

Notably, it appeared that this assessment was shared by Mao. In an enlarged session of the Politburo (zhengzhiju) in April 1956, Mao delivered a seminal speech, "On the Ten Major Relationships." This speech seemed to indicate that Mao was the primus motor in breaking away from the Soviet development strategy in favor of a strategy of "walking on two legs"30 (liang tiao tui zou lu):

The root cause of the failure to increase agricultural production in some countries is that the state's policy towards the peasants is questionable. The peasants' burden of taxation is too heavy while the price of agricultural products is very low, and that of the industrial goods very high ... Our current predicament is that we must appropriately adjust the investment ratios between heavy and light industry and agriculture and increase the development of agriculture and light industry.

MAO 1977, PP. 285-286

29 Karl Marx took it for granted that small-scale agricultural production was doomed: "Large industry and large agriculture on an industrial scale work together" (Marx and Engels 1990, p. 946). Engels, Kautsky and Lenin never questioned this basic assumption of Marx. Stalin followed in their footsteps by launching the collectivization drive in the late 1920 . Indeed, "On the Ten Major Relationships" has often been referred to in secondary literature to bolster the claim that Mao sought to fundamentally alter the Chinese strategy of economic development (see Simonis 1968). 
In fact, although Mao stressed more balanced development, he did not disassociate himself from the imperative of heavy industry growth:

In the future we must put more investment into light industry and agriculture so that the proportion of investment they receive is increased. When we increase this proportion, does this mean that we have changed the key sector? No, the key sector has not been changed. It is still heavy industry, but more emphasis will now be put on light industry and agriculture.

IBID.

As such, Mao sought not to radically alter the relationship between the economic departments, but still clung to the Soviet paradigm for economic development. The upturn in agricultural productivity was to be predominantly achieved through the aggregation of farmland in massive communes. The discussion on sectoral adjustment, however, came to serve as an entry point for a more comprehensive discussion regarding the mechanisms of coordination and distribution of control (Brødsgaard 1983a). Opinions diverged considerably on the appropriate distribution of fiscal influence over the center, local government and the collective. Chen Yun, who headed the State Capital Construction Commission (guojia jianshe weiyuanhui) was most radical in his perspective. Speaking at the eighth congress of the CCP in 1956, Chen-while careful to praise the great advances made toward the establishment of socialismemphasized a number of emerging problems. Chief among these were the deterioration of product quality and diversity within the consumer goods sector and part of socialized industry, and the decrease of rural non-agricultural production (Chen 1956). These problems, argued Chen, were a result, in no small part, to the premature abandonment of market prices.

The solution, in Chen's (1956) view, would be the partial reinstatement of the principle of market exchange within department 2 (i.e. the consumer goods sector), by substituting the unified planning system with a stratified system wherein planning and market exchange would coexist. Factories within department 2 would procure the objects of labor (i.e. raw material) themselves, and sell their output. By reinstating the principle of market exchange, factories were expected to become more attentive to the costs associated with the procurement and use of material, lest increases in the ratio of constant to variable capital would erode the rate of profit. ${ }^{31}$ The state would maintain a monopoly

31 Note that Marx, in distinction to neoclassical economics, understood constant capital to include the material inputs to production. The reason for this is that Marx used "constant" to denote that the value of this capital did not increase or decrease in the process 
on the purchase of commodities such as cotton, coal and sugar in order to ensure sufficient supplies and maintain market stability. In the purchase of consumption products for daily use, the state commercial departments would have priority, but remaining products could be marketed either by the factories, or by commercial departments acting as their commission agents. Within agriculture, too, market exchange and production prices were to assume a greater role. By allowing subsidiary agricultural production to be governed by the market, Chen stated, product diversity would be enhanced. Moreover, the reinstatement of production prices would allow production teams to retain part of their realized surplus value, which could subsequently be reinvested to expand subsidiary production. When, shortly after the eighth Party congress, Chen was elevated to the position of vice-chairman of the CCP, his proposals likewise increased in influence, and became a focal topic of discussion in China's leading economic journals. ${ }^{32}$

However, Bo Yibo, chair of the State Economic Commission, was convinced that economic success was strongly dependent on full exploitation of the "socialist advantage" of centralized planning:

No matter whether it concerns the deployment of construction or the allocation of investment, or the confirmation and planning of production indicators, whether it involves the adjustment and allocation of raw material and products, all of these must proceed from a holistic perspective, so as to guarantee the focal points and consider the general; our nation's limited labor, material and fiscal resources must be rationally utilized where the need is most pressing, their effect most prompt, and their use the greatest. To do this, we must most certainly consolidate command and unify planning.

BO 1956, P. 52

Within the State Planning Commission (guojia jihua weiyuanhui), by contrast, a concern arose that centralized planning was unfit to effectively deal with the

of production (but merely transform). By contrast, only labor can increase the value of materials, through the latter's refashioning in novel products.

Thus, writing in the journal Jihua Jingji, Xue Muqiao (1957a; 1957b), the director of the State Statistical Bureau, agreed with Chen Yun regarding enlarging the role of the market in order to stimulate economic growth. In articles published in the journals Tongji gongzuo and Jingji Yanjiu, Sun Yefang $(1956$; 1957) went even further by arguing that all planning and statistical work should be based on the law of value and that profits should function as the main indicator of enterprise efficiency. 
diverse industrial conditions and demands of the localities. Therefore, members of the commission advocated decentralization of control to subnational levels of government (Donnithorne 1964).

The opinions of Bo and Chen pitted them against Mao, who had great reservations about the proliferation of central bureaucracy and categorically dismissed the possibility of introducing market allocation. The consolidation of economic decision-making power within the bureaucratic planning organs could potentially undermine the authority of the CCP, which was based on the support of the masses (Lieberthal 1997). Likewise, the notion of introducing capitalist relations of production contravened Party ideology. Mao insisted that "basic construction ought to strengthen the leadership of the Party and mobilize the masses" (1958). Mao's statement reflected his strong emphasis on the development of the "socialist consciousness" at the expense of the technical requirements of production. Chen Yun's proposal would eventually cause an ideological rift between the economic bureaucracy, whose perspective on economic development emphasized the technological qualities of economic production and coordination, and a more radical Party faction, in favor of a strategy of mass mobilization (Lieberthal 1997).

\section{The Great Leap Forward (1958-1959)}

The Great Leap Forward was Mao's response to three prominent issues within economic discourse. First of these was the aforementioned emergence of a "rightist" faction of economic leaders advocating the introduction of market forces. Second was the strategic issue of the imbalance between the agricultural and industrial sector that had arisen under the First Five Year Plan. Third, and straddling both of these issues, was concern about "major domestic contradictions" (zhuyao guonei maodun), which primarily related to the relations of production.

According to Mao, the central economic issue was that of the relations of production, and not the productive forces. Mao advocated a continuous revolution of the relations of production, consisting of changes in the ownership system, the relations among the agents within the production process and the system of distribution (Christensen and Delman 1983). Of these, Mao considered the transformation of ownership to be most important. In his "Reading Notes on the Soviet Union's 'Political Economy', Mao stated: "The revolution in the system of ownership is the base, so to speak" (1969, p. 347). This statement was motivated by Mao's belief that the socialization of ownership would spur on the development of productive forces (i.e. the economic foundations): "First the relations of production have to be changed, then and only then can the productive forces be broadly developed. This rule is universal" (ibid., 
p. 370). ${ }^{33}$ However, Mao believed that completion of the transition toward truly communist relations of production could not occur instantaneously, but would be contingent on having first completed structural transformation from an agricultural to industrialized economy. Until then, ownership would have to be invested in large communes. Not only did communal ownership serve as an intermediary approximation of communist organization of labor (as opposed to the capitalist "recidivism" advocated by Chen), but the construction of the communes would also serve to intensify the collectivization of agriculture, thereby providing both the socialist impetus and technical economies of scale and labor surplus necessary to realize an upturn in both agricultural and industrial productivity. ${ }^{34}$

In the years directly following the First Five Year Plan, the issues of "rightism," productivity and domestic contradictions became the focal point of politics. At the third interim meeting of the eighth plenum of the ССP in September and October of 1957, an anti-rightist ( fan youpai) campaign was launched seeking to purge the Party of revisionist elements. Chen Yun was ousted from politics in $195^{8}$, to return only after the failure of the Great Leap had become undeniable. Absent political opposition, the second session of the eighth Party congress, held in May of that year, was used to formally endorse the strategy of the Great Leap. The strategy consisted of two main components. First was the aforementioned establishment of the people's communes. In 1958 the size of rural cooperatives was greatly expanded, from an average 160 to over 5,00o households (Dixon 1982, p. 4). In tandem with these structural reforms, the Party-state decentralized much of its administrative authority to the levels of local government and the communes. While the center still issued its production quota, the technical instrument of central planning was suspended in favor of a strategy of mass struggle, based on the "socialization of consciousness." The socialization of the relations of ownership was reflected in the expansive welfare arrangements extended to the workers in the communes. The expansion of socialist awareness was further buttressed by massive propaganda campaigns stressing the crucial nature of continuous struggle (Shambaugh 2007).

These adjustments to economic organization, alongside a bumper harvest in 1958, bolstered the Party's conviction in its capacity to realize a tremendous upsurge in economic output. On the basis of the anticipated economies of

33 Mao seems to have derived this conclusion through empirical observation: "From the standpoint of world history, the bourgeois revolutions and the establishment of the bourgeois nations came before, not after, the industrial revolution" (1969, p. 346). 
TABLE 3 Planning the Great Leap Forward:Production quota for grain and steel output for the year 1962

\begin{tabular}{lll}
\hline & Grain (Ton) & Steel (Ton) \\
\hline September 1956 & $500 \mathrm{~m}$. & $10-12 \mathrm{~m}$. \\
August 1958 & $1.5 \mathrm{bn}$. & $80 \mathrm{~m}$. \\
June $1961^{*}$ & $310-320 \mathrm{~m}$. & $10 \mathrm{~m}$. \\
Realized in 1962 & $160 \mathrm{~m}$. & $6.7 \mathrm{~m}$. \\
\hline
\end{tabular}

* Quota for 1963 .

SOURCES: ZHOU (1956); GUOJIA JIHUA WEIYUANHUI DANGZU (1961); GUOJIA JIHUA WEIYUANHUI DANGZU (1958).

scale in agricultural production, the target for agricultural output was significantly adjusted upward. However, the potential to transfer surplus labor to department 1a caused production targets within industry (notably steel) to be increased by an even greater margin (see Table 3$) \cdot{ }^{35}$

Although the Great Leap Forward introduced significant changes into management and organization in both industry and agriculture, ${ }^{36}$ it constituted an intensification, rather than a mitigation of or deviation from the Soviet strategy of accelerated accumulation. When Minister of Defense Peng Dehuai stated his grave concerns regarding the consequences of the Great Leap at the Lushan conference in 1959, Mao responded by removing Peng from his position and instigating another round of anti-rightist campaigning. It was in fact not until 1960, when the failure of the Great Leap had become indisputable, that the intensified pattern of accumulation was abandoned. A series of floods and draughts in 1959 had caused agricultural output to be much lower

35 During the heyday of the collectives in 1958 , they came to account for approximately half of peasant incomes (Dixon 1982, p. 5).

36 In agriculture: the people's communes have no precedent in the Soviet policy on collectivization. In industry: the "Two participations, one reform and three combinations" system (participation of cadres in labor, workers in management, reform of rules and regulations, combination of leadership with the masses, labor with technique and technical theory with production practice) broke with the Soviet responsibility and incentive system of one-man management. These developments-although important-do not invalidate the argument that, as far as accumulation and the relationship between the main sectors goes, the Great Leap Forward represented intensification rather than a break with the Soviet strategy. 
than anticipated. Moreover, the strategy of communization had not exhorted laborers to work more expeditiously, but rather induced inefficient labor practices and overconsumption. Nevertheless, communes and local bureaucrats, eager to appease the center, grossly exaggerated production achievements. While agricultural output dropped in 1959 and 1960, state purchases of grain were conducted on the basis of inflated harvest figures (Lippit 1975). ${ }^{37}$ The result was a massive reduction in the amount of grain available for peasant consumption, which dropped to the low level of 92.5 billion kg in 1961, causing pervasive famine.

\section{Readjustment and Consolidation (196o-1965)}

As the full extent of the economic crisis resulting from the Great Leap became evident in 1960, Chinese leaders embarked on a course that significantly altered economic priorities. In this process Mao retreated to the "second line," occupying himself with foreign policy issues and ideology, and leaving the development of economic strategy to a group of senior Politburo leaders. ${ }^{38} \mathrm{In}$ the summer of 1960, a Central Work conference, convened at Beidaihe, decided to decisively change the priorities of economic policy. After this conference, the key slogan was changed from "simultaneously developing industry and agriculture with priority to be given to heavy industry" to "taking agriculture as the foundation and industry as the leading factor."

Key measures for addressing the problems of the rural people's communes were enacted in the November 1960 "Urgent Directive on Rural Work" (also known as the "twelve articles") ${ }^{39}$ and the May 1961 "Draft Regulations on the Rural People's Communes" (routinely referred to as the "sixty articles")..$^{40}$ An end was demanded to the policy of "one equalization and two transfers" (yi ping er diao), which had promoted egalitarianism amongst China's peasants by the communalization of farmland without compensation. Private plots, which had been confiscated in 1958, were returned to the peasants, and they were given permission to sell their products at rural trade fairs. The size of the communes, brigades and production teams was reduced and operational

37 Kung and Chen (2011) note that incentives for professional attainment also significantly contributed to administrators' extraction of grain output to meet central quota during the Great Leap Forward.

$3^{8}$ Amongst whom, notably, were Liu Shaoqi and Deng Xiaoping.

39 For example, the output quotas of the teams should be fixed low enough to allow teams to achieve a surplus that they could retain as a "bonus," see "Nongcun gongczuo jinji zhishi" (1960).

"Nongcun renmin gongshe tiaoli caocan" (1961). 
authority decentralized. Through a contract system, brigades negotiated output quotas with the teams, which the latter then would guarantee. Within the three-level commune structure, it was required that accumulation was to be reduced in favor of consumption. ${ }^{41}$ Furthermore, measures were introduced to avoid the excessive transfer of labor and resources from basic agricultural production to the many newly established commune-operated enterprises. ${ }^{42}$

Finally, production-based material incentives were extended (Teiwes 1979). Family sideline production was encouraged by allowing private plots on 5 percent of farmland acreage, and permitting trade on free markets after state quotas had been met. By these concessions official policy laid the basis for the so-called "three freedoms and one contract" (sanziyibao), that is, the extension of plots for private use, the extension of free markets, the increase in the number of small enterprises that had sole responsibility for their own profits or losses, and the fixing of output quotas based on the individual households. The sanzi yibao spread widely, resulting in the virtual dissolution of the commune structure in large parts of China. By 1962 it was reported that in certain areas as much as $30-50$ percent of land was under private cultivation (Chen 1969).

Important measures to deal with the crisis in industry were enacted in the December 1961 "Seventy Articles of Industrial Policy" (the "seventy articles"). ${ }^{43}$ The stipulations of this document clearly indicated that Great Leap Forward policies had been reversed. Except for specifically authorized projects, capital construction was halted, thereby decreasing the growth rate of heavy industry. All industrial enterprises established without considering economic rationality and efficiency were to be closed down. Industrial production was to be oriented toward the market, and should satisfy the needs of the consumers rather than being oriented toward its own enlargement. Attention was also given to

41 The changes introduced in agriculture during the liberal interlude of 1960-1965 would provide the blueprint for the comprehensive reforms instigated under Deng Xiaoping from 1978 onward.

42 During the Leap years, a major concern was to utilize rural labor in non-agricultural activities during the slack season. Apparently, the peasants were asked to do too much non-farming work, and only $5^{\circ}$ percent of the manpower was actually engaged in farm production (Tan 1960). As at least 80 percent of rural labor was necessary for farm work in the busy season, a severe labor shortage was reported (Ma 1961). Undoubtedly, the many newly established commune-run industries were partly to blame. The so-called "readjustment of labor power," i.e. bringing the peasants back to agricultural production had become a chief concern by mid-1960. Of more than 20 million workers recruited from the rural areas between 1958 and 196o, 20 million were sent back from the cities in 1960 to engage in agricultural production (Liu, S. 1980).

“Gongye zhengce qishitiao zhuyao neirong” (1961). 
improve the quality and variety of products. In sum, the new policies meant that capital investment had to be reduced, consumer goods industries and industries producing goods for the agricultural sector were to be prioritized, and quality rather than quantity was to be emphasized.

\section{Readjustment, Consolidation, Filling Out and Raising Standards}

At the ninth plenary session of the CCP convened in January 1961, the new official policy line was termed "readjustment, consolidation, filling out and raising standards" (tiaozheng, gonggu, chongshi, tigao). Readjustment (tiaozheng) referred to the correction of imbalances that had characterized the economy; most importantly: (1) an unduly high rate of accumulation, which had permitted little or no increase in living standards; (2) overaccumulation in heavy industry at the expense of light industry and agriculture; (3) overemphasis within heavy industry on metallurgical industries and neglect of such bottleneck sectors as energy and transportation. Consolidation (gonggu) and filling out (chongshi) pertained to the reinforcement of weak links in the production processes, the closing down of non-profitable enterprise and the concentration of production in efficient units. The filling out of existing capacity also involved completing essential projects and establishing a proper balance among various types of equipment within existing enterprises. Raising standards (tigao) related to improving the quality and variety of products, economizing on raw materials and fuel, and raising labor productivity.

The tenth plenary session of the CCP, convened in September 1962, noted that the policy of readjustment, consolidation, filling out and raising standards in the national economy and in strengthening the agricultural front had already yielded remarkable results. ${ }^{44}$ The plenum approved a document entitled "Resolutions on the Further Strengthening of the Collective Economy of the People's Communes and Expanding Agricultural Production," which reemphasized the important position of agriculture in the national economy and set the order of priority in the economic plan as agriculture first, then light industry and finally heavy industry. ${ }^{45}$ Moreover, the document stated that it was necessary to redefine the ratio of investment in conformity with the policy of designating agriculture as the foundation of the economy: "Investment in agriculture, including investments in industry, transportation, and scientific research which directly serve agriculture, should be systematically raised in proportion to the gross investment for economic construction." ${ }^{46}$

\footnotetext{
44 "Communique of the Tenth Plenary Session" (1971, p. 188).

45 "Resolutions on the Further Strengthening” (1971, p. 195).

46 Ibid., p. 196.
} 
The plenary session also approved a revised sixty-article document, the "Revised Draft Regulations on the Rural People's Communes." ${ }^{\text {"7 }}$ The draft regulations approved changes in the commune system that had taken place since 1961. Thus it was stipulated that production teams were to be the basic units of accounting and ownership in Chinese agriculture. The revised "sixty articles" also stipulated that the reorganized commune system would not be changed "for at least thirty years."

The new eight-character policy of "readjustment, consolidation, filling out and raising standards," giving priority to readjustment, entailed fundamental changes in the relationship between heavy industry, light industry and agriculture. ${ }^{48}$ The role of agriculture was no longer to function as an accumulation base for heavy industry growth, as had been the case during the First Five Year Plan and during the Great Leap Forward. Instead, agriculture was assigned top priority, which, among other things, meant focus on increasing agricultural mechanization, improving irrigation, increasing application of chemical fertilizers and accelerating electrification. In other words, the government aimed to channel larger investments into the agricultural sector and, within the heavy-industrial complex, prioritize those sectors that produced agricultural machines, chemical fertilizers and insecticides, electric pumps for irrigation purposes and power equipment (department $\mathrm{lb}$ output).

The changes within economic policy revived the debate on adjustment and reform that had been suppressed under the frenetic political climate of the Great Leap Forward. Whereas market and price reform had been the focus of the discussion during the "liberal interlude" of 1956-1957, the notion of readjustment now took center stage.

In the wake of the important Beidaihe conference of 1960 , it was mainly Hongqi (the leading Party publication) and the national papers Renmin Ribao (People's Daily) and Guangming Ribao that expounded on the consequences of the changing line for the relationship between accumulation and consumption. But after the ninth plenary session, China's preeminent economic journal, Jingji Yanjiu, also picked up on the discussion. The debate conducted in Jingji Yanjiu encompassed three distinct lines of thought. The first school of thought, which was dominant until the tenth plenary session, was represented by, among others, Liu Guoguang, Yang Jianbai and Wang Xiangming. They suggested

47 "Nongcun renmin gongshe tiaoli (xuizheng caoan)" (1962).

48 Because of difficulties in definition, the discussion about the distinction between heavy and light industry and this distinction's relation to the concepts of department 1 and 2 had been thriving since early 1957. For a thorough Chinese discussion containing references to articles on the subject, see Wang H. (1963). See also Chen (1967, p. 28). 
that China ought to continue to adhere to the Fel'dman-Preobrazhensky paradigm of economic growth, stressing the supposed long-term growth of overall productivity and associated increases in average consumption levels. Liu Guoguang was keenly aware of the political implications of this tradeoff between interests in short- and long-term consumption. To minimize the necessary duration of accelerated accumulation, he suggested that a large increment of surplus value would be reinvested in production materials and technology, so as to maximize the pace of reproduction (Liu 1962). Yang Jianbai likewise asserted that in the "early stage of socialist construction," the accumulation rate should be raised steadily in order to build up the foundation of heavy industry and to speed up expanded reproduction, but that it would be "inadvisable to continue raising the rate of accumulation year after year" once socialist construction had reached a certain stage, as "this is not compatible with the basic goal of socialist production: to raise the people's living standard" (Yang 1962). Wang Xiangming added the important caveat that "the effect on improving the relationship between heavy industry and agriculture resulting from arranging and adjusting the internal proportions of heavy industry is sometimes even more advantageous than the arrangement and adjustment of the total level of production of heavy industry" (Wang 1962). In other words, Wang argued that the manufacture of more machines for agricultural production might be more helpful to the development of department 2 than just cutting back the scale of heavy industry.

The remaining schools of thought developed in response to the decision of the tenth plenary session to increase the ratio of investment in agriculture and industry which "directly served agriculture." 49 The second perspective essentially extended the line of argument set out by Wang Xiangming. Thus, Yang Jingjie concurred that, during the First Five Year Plan, it had been necessary to emphasize the metallurgical and machine-building industries in order to rapidly establish a foundation for the industrialization of China. But with an industrial foundation basically established, it would be necessary to shift emphasis toward the agricultural sector. Accordingly, Yang advocated increasing capital construction investment in agriculture and department $1 \mathrm{~b}$, to promote the modernization (i.e. mechanization, electrification and use of chemical fertilizers) of the agricultural sector.

The third school, as it appeared in articles by Wang Xuzhuang and especially $\mathrm{Xu}$ Dixin, represented the first clear attempt to shift to a paradigm of economic thought that truly prioritized the development of agriculture. Wang Xuzhuang criticized the view that the rate of transfer of surplus value from agriculture

"Resolutions on the Further Strengthening" (1971, p. 196). 
was to be determined by the demands of industry. He claimed that in the final analysis, the rate of socialist reproduction was determined by the capacity of agriculture to generate surplus labor (i.e. surplus product). This surplus labor, argued Wang, is manifested in the commodities, food and raw materials not used for simple reproduction, whether in their initial form or transformed into accumulated capital through exchange for industrial products (Wang 1963, p. 21). Moreover, since the transfer of agricultural laborers to non-agricultural labor is dependent on increases in agricultural production and labor productivity, Wang argued that "the farm population that has changed to non-farm population is in reality a portion of the surplus labor created by agriculture." Finally, the scale of the agricultural market for industrial products also depended on the volume of agricultural production: "This is to say that it is not that the peasants are able to sell a large volume of agricultural products as a result of their purchases of a large volume for industrial products. The opposite is the truth." Accordingly, Wang concluded that the appropriate economic strategy would be to "arrange industrial production and construction and the speed and extent of their development in accordance with the capabilities determined by the supply of commodities, grain and raw materials, capital, labor and markets agriculture can provide" (Ibid., p. 27).

$\mathrm{Xu}$ Dixin went further still in emphasizing the predominance of the agricultural sector in economic development. He too stated unequivocally that the level of agricultural development determined the rate and scale of industrial development. He likewise reiterated Yang Jingjie's statement that industry must provide agriculture with sufficient technical equipment and facilitate the "technical transformation of agriculture," but added that the technical transformation of agriculture was the precondition for rapid industrial growth, not the other way around. Xu concluded that "the development of industry depends not only on the machinery, raw materials, and materials that can be provided by industry itself, but what is more important, on the quantity of marketable grain that can be provided by agriculture" (Xu 1962, p. 1). The view that, after completing the "technical transformation," agriculture would no longer serve as the foundation of the national economy was criticized by $\mathrm{Xu}$ Dixin. Agriculture remained the foundation "whether in the past, at present or in the future": "It is wrong to judge the role of agriculture as the foundation of the national economy simply on the basis of changes in the ability of agriculture to provide grain and labor." By unequivocally prioritizing the development of agriculture over that of heavy industry, Xu clearly departed from the Fel'dman-Preobrazhensky paradigm of economic growth and construction.

The Fel'dman growth strategy focused on extensive growth (extensive expanded reproduction). A sign of the shift to a new paradigm of economic 
thinking was that Chinese economists increasingly came to stress the importance of intensive growth (intensive expanded reproduction), that is, sources of growth that did not necessitate an increase in the accumulation rate and/ or the expansion of the industrial labor force. Dong Fureng (1963; 1964), for example, pointed to the importance of increasing labor productivity as a way of ensuring sustained growth, and Dong Yuanshi (1962) advocated a more efficient use of labor and capital. Although Mao had continued to advocate the principle of accelerated accumulation even in the wake of the Great Leap Forward,$^{50}$ his influence in economic affairs was waning in comparison to that of readjustment-minded leaders. Accordingly, agricultural development had become the main priority from 1961 onward ${ }^{51}$ Further development of this policy was, however, disrupted by the Cultural Revolution, which lifted Mao out of the relative obscurity of the second line and once again put the socialization of consciousness center stage.

\section{The Roles of Price and Profit Reevaluated}

In tandem with the discussions of the appropriate relations between the industrial and agricultural sector, the debate on the law of value and the associated concepts of concomitant price and profit reemerged. In his article "On Value," Sun Yefang (1959) related the economic malaise of the Great Leap directly to the neglect of the law of value. According to Sun, Chinese economists had been too eager to condemn the law of value, ${ }^{52}$ which they perceived to be inextricably related to capitalism and its vicious cycles of overexpansion and recession. While others had believed the vices of capitalism could be surmounted by abolishing private ownership and market production and exchange, Sun argued that stable and orderly economic development hinged on state control over prices. Nevertheless, if the (subjective) policies of government were to instill economic stability, they would have to adequately reflect the objective principles of value and utility. Thus, to Sun, the law of value was not the hallmark of capitalism, but rather a universal economic rule.

5o In his "Reading Notes on the Soviet Union's 'Political Economy'” (Mao 1969, p. 251), dating between 1960 and 1962, Mao stated that "priority growth in producing the means of production is an economic rule for expanded reproduction common to all societies."

51 "Guanyu yinfa di san ge wu nian jihua san ge wenjian de tongzhi" (1964).

$5^{2}$ In 1958, during the heyday of the Great Leap Forward, Chen Boda, then editor of the main Party periodical Hongqi and close confidant of Mao, had triumphantly proclaimed the demise of commodity production and the law of value. 
This perspective was not without its detractors. Dai Yuanchen (1964) maintained that the law of value was fundamentally at odds with the socialist system. In Dai's view the cost of labor within the capitalist system did not reflect the value created by labor, but rather the capitalist's capacity to extract surplus value through the subordination of the working class. Nevertheless, Sun's opinion on the importance of the law of value was shared by many of his contemporaries. ${ }^{53}$ This prompted extensive discussions on reform of the means of allocation (Lin 1981). The increased function of the law of value in regulating production depended crucially on determination of the rate of profit (i.e. surplus value). Up until then - and in line with the prescriptions offered by Stalin in his $195^{2}$ exposition-the 'profit' component in price formation had served solely as a means of national accounting, reflecting centrally stipulated rates of transfer between the agricultural and industrial sector. Following the pioneering work of Sun and others, ${ }^{54}$ economic discourse in the first half of the 196os came to center on the matter of how the instrument of profits could guide production in such a manner that it would accord with the law of value. Common to the various proposals was the notion that the increment of surplus value within a product's price would be somehow proportionate to that realized within the overall economy. ${ }^{55}$ Certain economists maintained that, in keeping with the traditional labor theory of value, the rate of profit ought to be determined on basis of the proportion of labor costs (Wang, Z. 1963; Bai 1964; He, Xue and Peng 1964). ${ }^{56}$ Others (Zhang and Zhao 1964) objected to such a method, arguing that the resultant increase of prices of agricultural products and commodities would effectively put a halt to the intersectoral transfers necessary to sustain accelerated accumulation. Instead they proposed profits should be computed rather as a fraction of production costs (which entailed both wages and material expenses).

In 1963, the most radical line of thought emerged (Yang 1963; He and Zhang 1964; Yun 1964). According to this perspective, productivity was primarily determined by the instruments of labor (i.e. capital) rather than labor itself.

53 Notably by Mao, who in 1959 condoned elaboration on the topic by stating that "the law of value is a great school; only if we use it, teach our millions of cadres and masses about it, can we build socialism and communism" (quoted in Lin 1981, p. 19).

54 For example, Xue Muqiao, who served as deputy director of the State Planning Commission and head of the State Price Commission (Guojiajiage weiyuanhui).

55 I.e. surplus value $(\mathrm{m})$ would be expressed as a fraction of total surplus value (M) realized within the economy.

56 See Marx and Engels (1990, ch. 45). 
Since greater productivity would imply a more parsimonious use of labor, strict observance of the labor theory of value would actually result in the comparative neglect of the most productive industries within the economy. Because capital, rather than labor constituted the primary determinant of productivity, the third school, also called the school of production prices, advocated that the rate of profit should be calculated on basis of the fraction of total capital employed in production of a particular commodity. According to critics this amounted thus to nothing less than a refutation of the Marxian labor theory of value, which formed the basis of the Chinese socialist economy.

\section{The Cultural Revolution}

In late 1965 , Mao, alarmed by what he perceived to be the emergence in China of the same revisionism that had corrupted the socialist cause in the Soviet Union, ${ }^{57}$ instigated the Cultural Revolution. During these turbulent years, leaders that had advocated economic reform and the readjustment of the strategy of economic development were once again ousted from positions of influence. In tandem, the academic discussion on reform and readjustment came to an abrupt end. Publication of Jingji Yanjiu and other economic journals propagating revisionist and intellectualist opinions ceased, not to reappear until 1978.58 With Mao once again at the political epicenter, the pattern of the Great Leap Forward reemerged. Thus, the emphasis on technological expertise faded as "redness" (i.e. ideological correctness) became the focal point of the Cultural Revolution, and mass struggle was once again prioritized over the revisionist technique of economic planning. The concurrent decentralization of decisions on industrial development and emphasis on ideological zeal prompted a volatile pattern of accumulation driven by local government. Local imbalances were compounded by the center, which initiated the construction of an inland industrial basis (Naughton 1988). The so-called Third Front (san xian) was to preclude the disruption of the national economy in the case of a foreign incursion by shifting industry toward the remote southern and western Chinese provinces and ensuring regional economic autarky through the establishment of cellular, self-sufficient regional industry. ${ }^{59}$ Notwithstanding the

57 See Mao $(1958 ; 1974)$.

$5^{8}$ The tone of the debate in Jingji Yanjiu already began to change by September 1964, and by the end of 1964 the attack on production prices had a wider aim: to question the whole spectrum of the reform program.

59 "Expediting the construction of the Third Front is a major strategic decision of tremendous historical significance made by the Chairman in 1964. We must heed the instructions of the Chairman and swiftly construct the Third Front, and gather the nation's labor, 
reconciliatory stance he had taken in the years directly following the First Five Year Plan, Mao would thus continue to insist on the implementation of the Fel'dman-Preobrazhensky paradigm during periods of political autonomy.

Although the Great Leap Forward and the Cultural Revolution have commonly been interpreted as erratic attempts by Mao to maintain his political significance in the face of the development of an increasingly independent state, Mao's strategy of mass mobilization, socialist indoctrination and militaristic production was in no manner inconsistent with his interpretation of the Fel'dman-Preobrazhensky paradigm. The dual requirement of developing the material (i.e. technical) and social popular consciousness within Marxian diagnostic economics left open the question of the prioritization of the two. Mao considered the revolutionary process of the socialization of consciousness the primary condition for the realization of accelerated accumulation and the eventual completion of the transition toward socialism. Thus, when faced with an insufficiently productive agricultural sector, the organizational form of the commune-which constituted an apparent advancement toward the communist ideal of ownership by the people, and moreover provided economies of scale which would allow for the transfer of rural labor toward industry - appeared as a logical solution. Yet, while under the movements of the Great Leap Forward and Cultural Revolution capital investments increased sharply, they also induced an unsustainable strain on agricultural production, systemic inefficiencies in allocation and a neglect of the technological conditions of production. These changes had been accompanied by a momentous change in discourse. Whereas the discussion of the economy in the early 1960 s had been characterized by exchanges between several schools of thought, during the Cultural Revolution the dogma of the revolutionary left became the sole legitimate line of thought. It would not be until the death of the Chairman and the subsequent ousting of the "Gang of Four" 60 in 1976 that political conditions allowed for the abolishment of the Fel'dman-Preobrazhensky paradigm and the politics of mass struggle.

material, finances so as to gradually build up the defence industry, natural resource, materials, fuel, power, machine and chemical industries and the transportation and logistics system, and let the Third Front become a large-scale strategic rearguard. This relates to the overall deployment of the third Five Year Plan." See "Guanyu di san ge wu nian jihua anpai qingkuang de huibao ti'an" (1965).

6o The Gang of Four (si ren bang), a strongly leftist clique comprised of Jiang Qing, Zhang Chunqiao, Yao Wenyuan and Wang Hongwen, rose to prominence during the Cultural Revolution. 


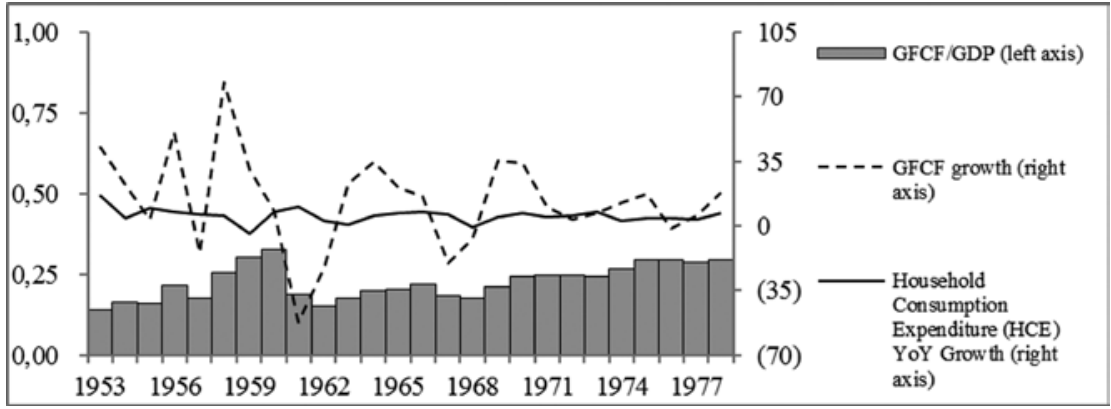

FIGURE 3 GFCF as ratio of GDP and percentage growth (\%), 1952-1978. SOURCE: NBS (2005, TABLE 10).

\section{Economic Development under the Maoist Economic Paradigm}

On the whole, economic development in the Maoist era displayed the distinctive characteristics of primitive socialist accumulation. GFCF consistently accounted for a large share of GDP (see Figure 3). The erratic pattern of growth of GFCF reflects the alternation of periods in which the Party-state pursued the rapid expansion of industry and a more balanced strategy of development.

During the Great Leap Forward the rate of GFCF shot up by 78 percent from 1957 to $195^{8}$, and at the end of the Great Leap, investments in gross fixed capital came to account for 32.5 percent of GDP. Not only did capital construction climb to excessively high levels in the Leap years of 1958-60, but the sectoral imbalances that had appeared under the First Five Year Plan period were greatly exacerbated (see Figure 4). Although the marginal increase in the proportion of funds for capital construction allocated to agriculture in 1958 was accompanied by a moderate increase in output, agricultural production stagnated in subsequent years. To some extent, the drop in agricultural output was precipitated by exceptionally bad weather, but economic reorganization gravely exacerbated problems. In order to achieve or exceed the industrial production targets set out in the national plan, local governments (whose operational mandate was significantly increased during the Great Leap) redirected a large portion of resources and labor from agriculture to the production of iron and other industrial input. The preoccupation with rapid industrialization likewise affected the agricultural communes, so that only some 5 o percent of commune workers were actually engaged in agricultural production (Tian 1960). As a consequence, the number of workers employed in industrial units almost doubled from 1957 to 1958 (NBS 2005, table 8). The economic reorganization of the Great Leap greatly aggravated the sectoral imbalances that had 


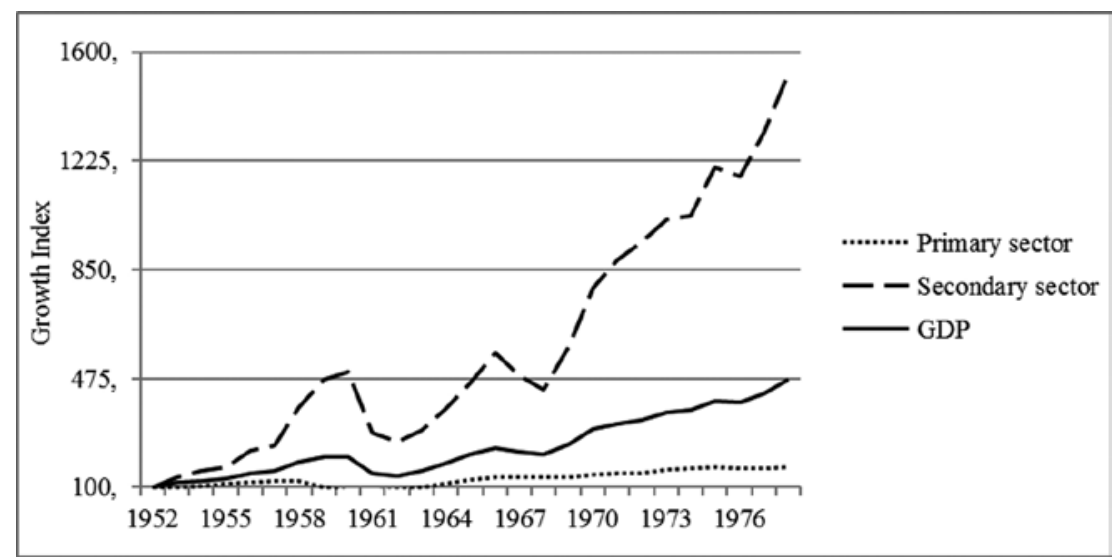

FIGURE 4 Growth indices of output of primary and secondary industry, 1952-1978. SOURCE: NBS (2005, TABLE 6).

emerged under the First Five Year Plan. Although, in 1957, total output realized in agriculture had surpassed that of industry by some 36 percent, by 1960 agricultural output was 47 percent less than that of industry. Clearly, these figures do not substantiate the proposition that the Great Leap Forward implied the abandonment of the strategy of primitive socialist accumulation in favor of a transition to a more balanced economic strategy of "walking on two legs," as has been argued by a number of scholars in studies published during and after the Cultural Revolution. ${ }^{61}$

The introduction of liberal policies following the calamity of the Great Leap prompted a temporary shift to a more moderate and balanced pattern of development. Under the banner of "readjustment, consolidation, filling out and raising standards," adopted in early 1961, all capital construction-save for a limited number of designated priority projects - was called to a halt. Moreover, inefficient newly established industrial enterprises were closed down. By 1961, GFCF dwindled to only 18.7 percent of GDP. Intersectoral adjustments likewise accorded with the new strategy of balanced growth. The transfer of agricultural labor to industry was reversed. In line with the emphasis on the modernization of agricultural production, investment in agricultural capital was also increased, reaching 23 percent of total expenditure on capital construction in 1963. The drive for the technical transformation of agriculture also impacted industry, causing a shift toward the production of agricultural producer goods (Stavis 1978). Due to these policies, agricultural output

61 See, for example, Eckstein (1975); Schurmann (1968); Teiwes (1979); Chesneaux (1979). 
rose by $9.8,12.4$ and 16.5 percent respectively from 1963 to 1965 . The liberal interlude in policymaking was instrumental in remedying the imbalances of the Great Leap.

However, Mao's return from the second line signaled the reinstatement of radical economic policies unequivocally prioritizing the development of heavy industry. Although efforts at accelerated accumulation were less volatile in the last decade of the Maoist era, by 1978 the proportion of GDP allocated to the formation of fixed capital had nevertheless climbed to a level comparable to that during the Great Leap. In consequence, investment ratios between the first and second economic departments (agriculture and industry respectively) throughout the Maoist era exhibited a much stronger bias toward the development of industry than proposed in the original Fel'dman-Preobrazhensky paradigm. High levels of investment in industry had been supported by the appropriation of agricultural revenues (by way of the so-called price-scissors mechanism, which depressed prices for agricultural produce). Indeed, the strategy of primitive socialist accumulation had caused China's industrial sector to grow by leaps and bounds.

However, the Fel'dman-Preobrazensky paradigm predicted that improvements in efficiency would eventually cause an upsurge in agricultural production. Such improvements failed to materialize (see Figure 4). Because of the CCP's preoccupation with industrial development, significant expenditure on the production of producer goods for the agricultural sector and investment in the development of basic conditions for agricultural production (irrigation, electrification etc.) had been confined to the period of readjustment in the first half of the 196os. Rather, the Party had continued to rely on reorganization (i.e. the establishment of large-scale farming collectives) and autonomous investment by the rural community. Although the reorganization of plots into large-scale collectives resulted in labor-saving economies of scale, they had but a marginal effect on overall productivity because rural labor participation had, from the outset, been comparatively low, and there were few alternative uses for idle rural workers. ${ }^{62}$ While China's labor force grew by some 191 million between $195^{2}$ and 1978, industry only absorbed about 37 percent of this addition (Naughton 2007, p. 81). On the one hand, there was an inherent limit to the extent to which capital-intensive industry could absorb the rural labor surplus. On the other, the covenant between the Party-state and the industrial worker was predicated on the latter's subjugation to the Party-state apparatus in exchange for a comparatively high wage and entitlement to a wide array

62 The average rate of rural labor participation between 1952 and 1978 was 38.8 percent, and displayed only marginal variation (NBS 1998). 
of welfare benefits. Rapid expansion of the industrial workforce would have depressed wages and attenuated the Party-state's capacity for monitoring and control. Thus, the state relied on the household registration system to enforce a stringent constraint on the mobility of rural inhabitants. ${ }^{63}$

The limited capacity of industry to absorb excess agricultural labor was reciprocated by the lack of rural purchasing power, which further prevented the diffusion of industrial products to the agricultural sector. What growth the sector experienced did not result in a commensurate increase of rural affluence; whereas total agricultural output had grown roughly five times between $195^{2}$ and 1977 (the year preceding agricultural reform), per capita consumption expenditure had only doubled. ${ }^{64}$ Moreover, since production was subject to quota and appropriated by the state at depressed prices, peasants had arguably little incentive to autonomously increase production. ${ }^{65}$ Due to the lack of investment in agricultural modernization and limits to the rationalization of the structure of rural labor, production of grain per peasant remained virtually stagnant throughout the plan era, reaching 0.90 cubic meters in 1952 and 0.93 in $1977{ }^{66}$ In spite of the failure to vitalize agriculture, industry expanded rapidly, growing from around 18 to just under 45 percent of GDP from 1952 to 1978.

Inefficiencies within industry compounded the structural problems of the plan economy. The institutionalized emphasis on accelerated growth coalesced with soft budget constraints, resulting in persistent resource shortage (see Kornai 1980). Moreover, because the CCP sought to ensure fidelity to its leaders and the precepts of communism, the incentives of industrial workers were only partially based on economic achievements. All in all, after nearly three decades of economic development under the Fel'dman-Preobrazhensky paradigm, the Chinese state had failed to achieve the national economic prowess envisioned at the beginning of communist rule.

63 From the mid-195os onward, the government utilized an extensive administrative apparatus (the household registration or hukou system) to monitor and control all domestic movement of labor. This registration system allowed the government to restrict movement from countryside to city, so as to realize the desired distribution of labor between agriculture and industry. Curbing the inflow of urban migrants was required to ensure appropriate incentives for cooptation of the industrial workforce (Cheng and Selden 1994). Moreover, by preventing the free movement of industrial labor, the registration system provided a prerequisite for the project of sociopolitical transformation, which sought to supplant traditional social relations (of family, region etc.) with ties to the factory or commune (Walder 1988).

64 Calculated from NBS (2005, tables 4, 38).

65 Essentially, the problem was one of rent-seeking, see Murphy, Shleifer and Vishny (1993).

66 Calculated from NBs (2005, tables 4, 39). 
Despite repeated calls to depart from the principle of accelerated accumulation in favor of a more balanced trajectory of growth, attempts to adjust the relationship between agricultural and industry in favor of the former were consistently rebuffed by the demagogic politics of the Chairman, whose personal influence in politics was insuperable. The aggregation of authority in the person of Mao, however, also caused the development of a political vacuum after his death in September 1976, enabling Deng Xiaoping to finally introduce the reforms and readjustments that had been debated from $195^{8}$ onward. Thus, despite Herculean effort and great expense, attempts to match the accomplishments of the modern industrialized economies within a generation by way of the "productive advantage" of socialist economic organization fell decisively short of the mark. Throughout the era of the plan economy, China maintained a high ratio of fixed gross capital formation to $G D P,{ }^{67}$ and the average growth rate of the economy during the period $195^{2}$ to 1978 reached 6.7 percent. Although certainly robust, economic growth was nowhere near large enough to realize the objective of matching the productivity of the industrialized capitalist economies within a generation. Nevertheless, through establishment of the material conditions for the development of a modern economy, and by providing the conceptual premises for reform and development, the Maoist era had furnished the requisite conditions for the subsequent development of the socialist market economy (Hung 2016).

\section{Conclusion}

Based on Soviet precedent, the Maoist strategy for economic development followed the principles of primitive socialist accumulation, whereby agricultural commodity production was to furnish the capital for rapid industrialization. Manufacture of production goods would in turn increase the efficiency of agricultural production, so that the absolute levels of output of both the primary and secondary sectors would eventually surpass that realized under a trajectory of balanced growth. As outlined in the preceding section, the strategy of accelerated accumulation fell decisively short of its mark. Observant leaders and economists had already warned about the defects of Chinese economic policy during the period of the First Five Year Plan. Their recommendations comprised two central elements, readjustment (tiaozheng) and reform

67 Ranging from 0.25 in the First Five Year Plan period (1953-1957) to 0.34 during the period of the Fourth Five Year Plan (1971-1975), See Joint SsBC-Hitotsuhashi Team (1997). 
(gaige). Initially, discourse emphasized readjustment, that is, the transformation of relations between departments 1 (producer goods) and 2 (consumer goods). Early discussions of reform - relating to the respective roles of the law of value and planned, proportionate development - were, by and large, confined to extending the passive role of exchange values in the planning of commodity production. ${ }^{68}$

Whereas it has been argued that the debate of readjustment gave occasion for Mao to break with the strategy of primitive socialist accumulation in favor of a policy of "walking on two legs" (see Teiwes 1979), the intensification of the expropriation of agricultural output under the Great Leap Forward belies such assertions. From Mao's writings, we can infer that, in his analysis, the problems of economic development owed nothing to any fundamental flaws in the technical matters of sectoral development or the instruments of allocation, but rather to the underdevelopment of socialist consciousness and the relations of production. By this interpretation, the revolutionary events of the Great Leap Forward and the Cultural Revolution were logically consistent with Mao's convictions, although disastrous in outcome. However, in the wake of the ideological frenzy and grave economic imbalances of the Great Leap, the discussions on readjustment and reform continued with yet greater intensity. Hence, economists and state leaders sought to overturn the initial prioritization of industry, and extend the role of the law of value in resource allocation. Major advancements along these lines were made in the realm of agriculture between 1960 and 1965 . The introduction and subsequent expansion of the policy of sanzi yi bao allowed for the private use of part of farm plots and sale of a portion of produce on the market, and would provide much of the input for Deng's agricultural reforms of 1978. However, the instigation of the Cultural Revolution brought about a return to Maoist principles. All in all, the basic features of primitive socialist accumulation, that is, a consistently high rate of accumulation and the prioritization of industry over agriculture, predominated within Maoist-era economic development.

The constant juxtaposition of, and contention between, material conditions and consciousness, and productive factors and relations of production in Maoist-era discourse, resulted in an ideological rift between Party and state (Lieberthal 1997). Mao and, in a more general sense, Party leadership had disapproved of the explicit coercion to which Stalin had resorted to further the cause of socialism. Therefore, the emphasis of Party leadership was on the cultivation of socialist awareness through political campaigns and

68 And thus largely consistent the prescriptions provided by Stalin ([1952] 1972). 
the reengineering of social relationships. The Party's preoccupation with the eradication of capitalist vestiges clashed with the technical reforms proposed by China's economists, many of whom occupied key positions within the economic bureaucracy or served as advisers to the heads of the central economic commissions. It is not surprising then that once Mao's political attacks on rightism and revisionism abated in the latter years of the 1970s, readjustment and reform became the unequivocal focus of state leadership. 